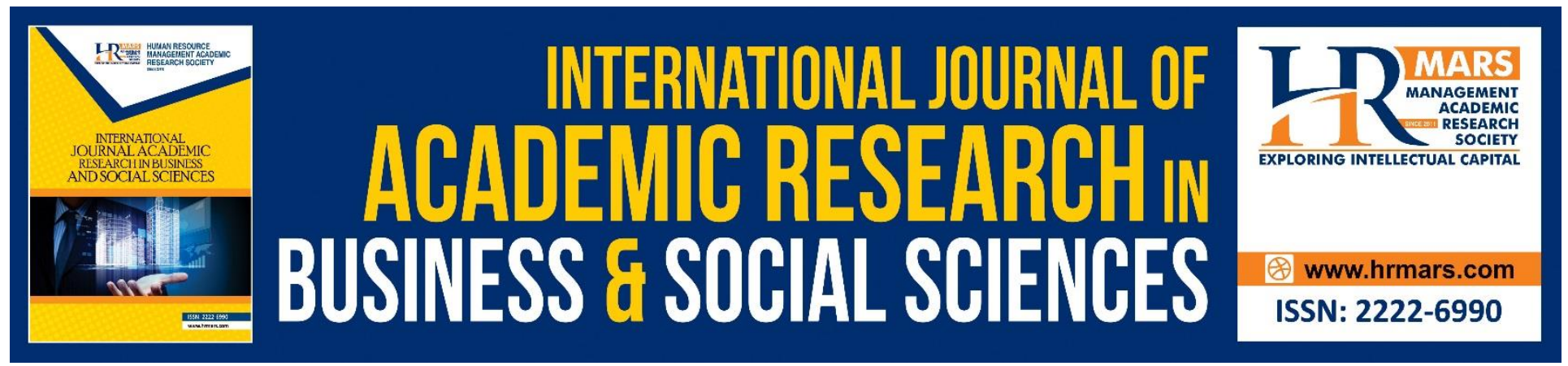

\title{
Efficacy of Doctor WoRM's Module for Year Four Low Achievers
}

Yoong Soo May \& Noor Aini Ahmad

To Link this Article: http://dx.doi.org/10.6007/IJARBSS/v8-i10/5314

DOI: $10.6007 /$ IJARBSS/v8-i10/5314

Received: 21 Sept 2018, Revised: 27 Oct 2018, Accepted: 02 Nov 2018

Published Online: 05 Nov 2018

In-Text Citation: (May \& Ahmad, 2018)

To Cite this Article: May, Y. S., \& Ahmad, N. A. (2018). Efficacy of Doctor WoRM's Module for Year Four Low Achievers. International Journal of Academic Research in Business and Social Sciences, 8(10), 1576-1585.

\section{Copyright: (C) 2018 The Author(s)}

Published by Human Resource Management Academic Research Society (www.hrmars.com)

This article is published under the Creative Commons Attribution (CC BY 4.0) license. Anyone may reproduce, distribute, translate and create derivative works of this article (for both commercial and non-commercial purposes), subject to full attribution to the original publication and authors. The full terms of this license may be seen

at: http://creativecommons.org/licences/by/4.0/legalcode

Vol. 8, No. 10, 2018, Pg. 1576 - 1585

Full Terms \& Conditions of access and use can be found at http://hrmars.com/index.php/pages/detail/publication-ethics 


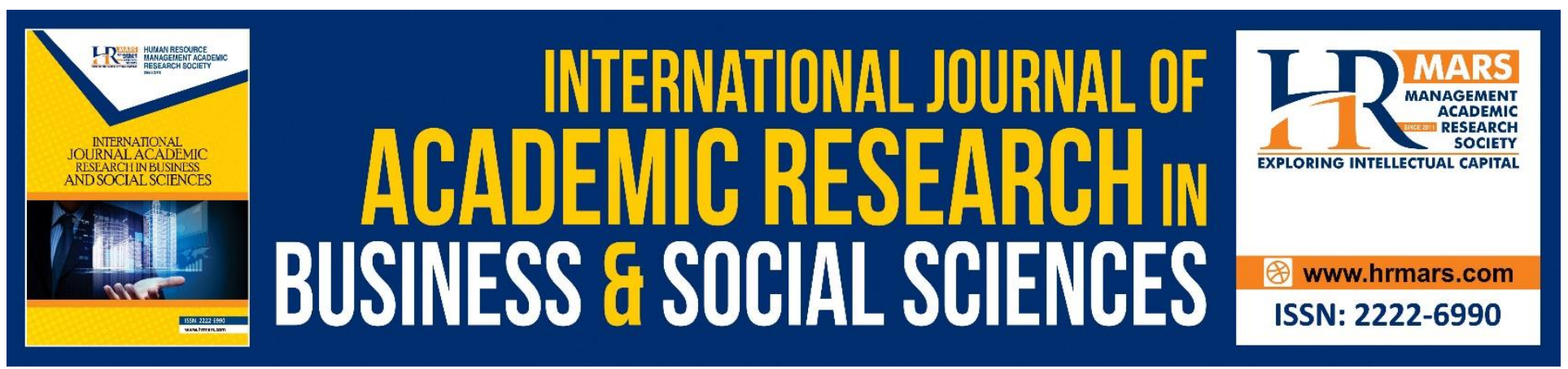

\title{
Efficacy of Doctor WoRM's Module for Year Four Low Achievers
}

\author{
Yoong Soo May \\ Department of Special Education, Faculty of Human Development \\ Sultan Idris Education University, Malaysia. \\ Noor Aini Ahmad \\ Department of Special Education, Faculty of Human Development \\ Sultan Idris Education University, Malaysia.
}

\begin{abstract}
Mathematics is a core subject teaching in primary school education in Malaysia. Every pupil has to be mastered in four basic arithmetic skills. In this case, single-digit multiplication is important as it is the basis for other mathematics operations. However, there are still some pupils who face challenges in the skills even by Year Four. In this study, the researcher had carried out a quasi-experimental study to determine the efficacy of DoCtor WoRM's Module. A pre-test was carried out to select the pupils who have not mastered the multiplication skills. Sixty pupils from four National-Type Chinese Primary Schools were selected as the respondents in this study. They were divided equally into experimental and control groups. The experimental group went through a teaching and learning using DoCtor WoRM's Module, while the control group learnt the same content using traditional teaching. Three months of intervention was carried out. Then, a post-test was carried out to both groups of respondents. Data was analysed using inferential analysis. Dependent $t$-test had showed that there was a significant increase in the achievement in multiplication skills from pre-test $(M=59.47, S D=$ 27.242 ) to post-test $(M=91.53, S D=12.566)$. The independent $t$-test showed that the achievement of multiplication skills in post-test of experimental group $(M=91.53, S D=12.566)$ is higher than the post-test of control group $(M=79.19, S D=22.588)$. As a conclusion, DoCtor WoRM's Module is effective in improving multiplication skills among Year Four low achievers in SJKC. This study implicated that module is an effective tool for low achievers to improve their mathematics learning. Keywords: multiplication, mathematics, low achievers, module.
\end{abstract}

\section{Introduction}

Mathematics is seen as an essential qualification in exam-orientated cultures for many countries (Sangster, 2016). The purpose of mathematics education is to ensure that all learners can apply basic 
techniques of number and measure in everyday life situations. This area of mathematics is also known as numeracy or functional mathematics (Penny, 2017). However, mathematics is often a subject that is not a favourite for teachers (Briggs \& Davis, 2015). Many students find it as a difficult subject, especially the low achievers.

Students with learning difficulties typically have under-developed knowledge, or gaps or misunderstandings in mathematical concepts and skills (Goos et al., 2017). In order to solve this problem, a mathematics teacher should aim to maximize effectiveness of struggle or effort while minimizing the frustration of these students while learning mathematics (Finesilver \& Rodd, 2017). The researcher had developed a module entitled DoCtor WoRM's Module in order to assist mathematics low achievers in this subject. Hence, an experimental study had been carried out to determine the efficacy of DoCtor WoRM's Module for Year Four low achievers.

\section{Background of the Study}

In year 2009, Malaysia first participated in the Programme for International Student Assessment (PISA). Based on the mean score for year 2012, Malaysia is still placed in the bottom third, ranking 52 out of 65 countries and 55 out of 74 countries in year 2009 survey (Kang, 2013). Through the Educational, Literacy and Numeracy Screening (LINUS) was introduced in August 2009. LINUS programme as an educational part of National Key Result Areas (NKRA) in Government Transformation Proramme (GTP) is continuity from the existing programmes to overcome the challenges in mastering basic skills of reading, writing and arithmetic (3M) systematically. The implementation of LINUS programme targeted 100 percent of Year Three pupils to master in literacy and numeracy before enter Year Four starting in year 2013, except for pupils with special needs. In line with this, DoCtor WoRM's Module as an intervention to improve multiplication skills among low achievers had been carried out. The efficacy of DoCtor WoRM's Module had been determined.

\section{Problem Statement}

esearches on identifying effective teaching and learning strategies are needed in Malaysia especially for the low achievers (Yusof, 2011). In this study, the efficacy of DoCtor WoRM's Module was determined and discussed. The aim of this study is to determine the efficacy of DoCtor WoRM's Module in improving multiplication skills among Year Four low achievers in National-Type Chinese School (SJKC). It had been done by identifying the difference between the means of pre-test and posttest for the experimental group, and the difference between the means of post-test for the control and experimental groups.

\section{Literature Review}

The literature review includes mathematics as a subject, multiplication and low achievers.

\section{Mathematics as a Subject}

Mathematics is the abstract study of topics such as quantity, numbers, structure, space and change. Through the use of abstraction and logic, mathematics developed from counting, calculation, measurement and the systematic study of the shapes and motions of physical objects (Ziegler \& Loos, 
2014). Mathematics is recognized as a foundation of Science, technology and intellectual development. It is also an index of civilization evolution (Chang \& Yang, 2016). Mathematics is one of the most important subjects yet some pupils face difficulties in learning it, especially the low achievers (Yoong \& Ahmad, 2018). Hence, interventions need to be carried out in order to assist low achievers to improve their mathematics subject. DoCtor WoRM's Module is believed to be able to improve the low achievers' performance in this subject, and its efficacy had been determined in this study.

\section{Multiplication}

Multiplication is one of the basic operational skills that must be mastered by the pupils. However, low achievers might not be able to acquire this skill as planned in the syllabus due to the different level of verbal working memory (Yoong \& Ahmad, 2018). Knowledge of the multiplication facts is essential for work with fractions and ratios (Emerson \& Babtie, 2014). A classic difficulty for people who are dyslexic or dyscalculic is with multiplication tables. Leaners may be unable to memorise the tables and, unless shown how to make sense of them, may not be able to use any of the facts in any meaningful way (Bird, 2012). The researcher found out that the low achievers face difficulties in single-digit multiplication during the needs analysis assessment survey. Hence, a module entitled DoCtor WoRM's Module is used as an intervention in order to help the low achievers in improving their single-digit multiplication skills.

\section{Low Achievers}

Low achievers are a special group of non-disabilities children who have difficulties to acquire fundamental knowledge during learning process in class (Ahmad \& Mutalib, 2016). These pupils have low motivation level in mathematics learning (Rahman, 2016). In other words, low achievers are less effective or less knowledgeable learners who needed to learn gradually and progressively with proper guidance (Hsieh, Lee \& Su, 2013).

In Malaysia, pupils' academic achievement is a significant concern of most parents, teachers and school administrators, especially for those who are involved with educating the low achievers whose numbers are on the rise (Ishak, Yunus, Rahman \& Mahmud, 2010). In short, even though low achievers are slower to make academic achievement as compare to other peers, but they are able to learn and having potential to achieve in academic. Hence, DoCtor WoRM's Module had been developed to assist the low achievers in learning mathematics.

\section{Methodology}

The purpose of this study is to determine the efficacy of DoCtor WoRM's Module in improving multiplication skills among Year Four low achievers. Based on the purpose of this study, the researcher employed a quasi-experimental design. The participants were divided equally into control group and experimental group. 
INTERNATIONAL JOURNAL OF ACADEMIC RESEARCH IN BUSINESS AND SOCIAL SCIENCES

Vol. 8, No. 10, Oct. 2018, E-ISSN: 222 2-6990 @ 2018 HRMARS

Table 1

Quasi-Experimental Design

\begin{tabular}{cccc}
\hline Group & Pre-Test & Teaching Method & Post-Test \\
\hline Experimental Group & T1 & DoCtor WoRM's Module & T2 \\
Control Group & T1 & Traditional & T2 \\
\hline
\end{tabular}

Table 1 shows the model of quasi-experimental design to determine the efficacy of DoCtor WoRM's Module in the teaching of multiplication skills among Year Four low achievers. The participants went through a pre-test, then a treatment for the experimental group, whereas the control group learnt through traditional method. After that, both groups went through a post-test. The pre-test is to ensure the two groups are equivalent before the intervention is taking place, whereas the post-test is to compare the achievement of control group and experimental group.

\section{Sampling Criteria}

he selection of sample in this study can represent the variable of the target population and shared the same characteristics. Population in this study is all Year Four low achievers in Manjung district in year 2018. The researcher had chosen four National-Type Chinese Primary School (SJKC) in Manjung district. These schools were selected because there were pupils who fulfilled the criteria as the samples according to the specific purpose of the study. The criteria of choosing the sample are; (1) studying in SJKC; (2) Year Four; and (3) scored less than 40 marks in previous mathematics assessment.

\section{Instruments}

Two instruments used in this study are; (1) pre-test and post-test; and (2) DoCtor WoRM's Module. There are three materials in DoCtor WoRM's Module; (1) Teacher's Manual; (2) Pupil's Activity Book; and (3) interactive game.

The purpose of pre-test and post-test as an instrument is to test the pupils' achievement level before and after the teaching and learning process. All of the 60 samples from control group and experimental group had participated in pre-test and post-test. The scope of the pre-test and posttest is the multiplication facts from three to nine.

On the other hand, DoCtor WoRM's Module consisted of three materials, which are Teacher's Manual, Pupil's Activity Book and interactive game. Teacher's Manual had been distributed to every teacher in the experimental group. It contained the introduction, objectives and background of DoCtor WoRM's Module. It also provided lesson plans on how to implement this module in the teaching and learning activities.

Pupil's Activity Book had been distributed to 30 pupils in the experimental group. This activity book acts as a reinforcement activity for the skills that had been learnt in that particular lesson. Besides, DoCtor WoRM's Module also consisted of a multimedia interactive game. Teachers used this 
INTERNATIONAL JOURNAL OF ACADEMIC RESEARCH IN BUSINESS AND SOCIAL SCIENCES

Vol. 8, No. 10, Oct. 2018, E-ISSN: 2222-6990 ㄷ 2018 HRMARS

interactive game for pupils in the experimental group. The pupils played this game after the learning activity on a certain multiplication facts.

Validity and Reliability of the Instrument

DoCtor WoRM's Module had been sent to seven experts to evaluate its content validity. The expert panel consisted of three experts in Remedial Education, three experts in mathematics, and one expert in module.

Table 1

Content Validity for DoCtor WoRM's Module

\begin{tabular}{ccc}
\hline Part & Component Module & Content Validity \\
\hline A & Teacher's Manual & .88 \\
B & Pupil's Activity Book & .87 \\
C & Interactive Game & .85 \\
D & Whole DoCtor WoRM Module & .86 \\
\hline
\end{tabular}

Table 1 shows the content validity of DoCtor WoRM's Module according to four different parts. The content validity of Part A Teacher's Manual is .88, Part B Pupil's Activity Book is .87, Part C Interactive Game is .85 and Part D Whole DoCtor WoRM's Module is .86. Overall, the content validity for DoCtor WoRM's Module is .86.

A module is considered to have a high content validity if the level of content validity achieved .70 (Nordin, 1995, in Noah \& Ahmad, 2005; Tuckman \& Waheed, 1981). Hence, DoCtor WoRM's Module had achieved a high content validity because the content validity is .86 .

In this study, the correlation coefficient, $r$ is used to determine whether there is a linear relationship between the scores of pre-test and post-test. The analysis using Pearson's correlation had shown that there is a significant linear relationship between pre-test and post-test. The correlation coefficient reported in SPSS statistics is $r=.723$. According to Elliot and Woodward (2016), when $r$ is greater than .50, the effect size is large. Thus, DoCtor WoRM's Module has a significant reliability based on the results of this Pearson's correlation analysis.

\section{Findings}

The efficacy of DoCtor WoRM's Module had been determined through comparison of the means between pre-test and post-test for the experimental group. It is to ensure that the mean score of the post-test is higher than the mean score of the pre-test. The intervention had been carried out for a three months period.

Figure 1 shows the score of pre-test and post-test for the experimental group. Overall, the average mean of improvement for experimental group is 32 percent. Null hypothesis in this study is [there is no significant difference between the mean of pre-test and post-test for the experimental group]. 
INTERNATIONAL JOURNAL OF ACADEMIC RESEARCH IN BUSINESS AND SOCIAL SCIENCES

Vol. 8, No. 10, Oct. 2018, E-ISSN: 222 2-6990 @ 2018 HRMARS

Meanwhile, alternative hypothesis in this study is [there is a significant difference between the mean of pre-test and post-test for the experimental group].

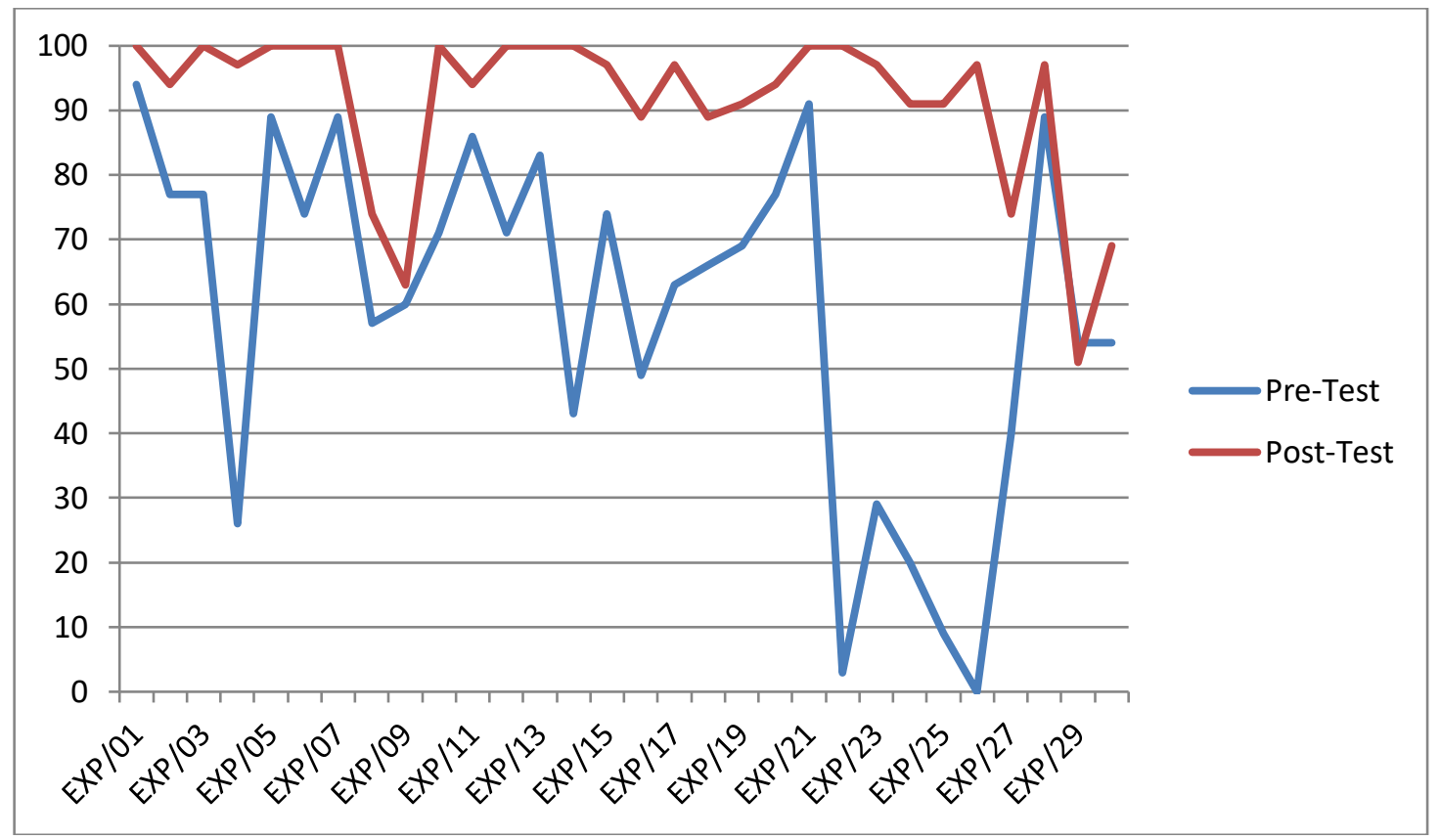

Figure $1 \quad$ Score of Pre-Test and Post-Test for Experimental Group

Table 2

Results of Dependent T-Test using SPSS

\begin{tabular}{cccc}
\hline Test & Mean & $\begin{array}{c}\text { Standard } \\
\text { Deviation }\end{array}$ & $\begin{array}{c}\text { Standard Error } \\
\text { Mean }\end{array}$ \\
\hline Pre-Test & 59.47 & 27.242 & 4.974 \\
Post-Test & 91.53 & 12.566 & 2.294 \\
\hline
\end{tabular}

Table 2 shows the results of dependent $t$-test by using SPSS. The mean of pre-test is 59.47 percent, with the standard deviation of 27.242 and standard error mean of 4.974. On the other hand, the mean of post-test is 91.53 percent, with the standard deviation of 12.566 and standard error mean of 2.294. The $p$-value for this dependent $t$-test is .00 . Since $p=.00 \leq .05$, so null hypothesis is rejected while the alternative hypothesis is accepted. Hence, there is a significant difference between the means of pre-test and post-test for the experimental group.

Since there might be some other external variables that controlled the improvement of the pupils' achievement, so another comparison of means between the post-test of experimental and control groups had been carried out. It is to ensure that the improvement by the experimental group is more significant than the improvement by the control group. 
INTERNATIONAL JOURNAL OF ACADEMIC RESEARCH IN BUSINESS AND SOCIAL SCIENCES Vol. 8, No. 10, Oct. 2018, E-ISSN: 222 2-6990 @ 2018 HRMARS

Figure 2 shows the score of post-test for experimental and control groups. Overall, the difference between the mean of post-test for experimental and control groups is 12.36 percent. Null hypothesis in this independent t-test is [there is no significant difference between the mean of post-test for the experimental and control groups]. Meanwhile, alternative hypothesis is [there is a significant difference between the mean of post-test for experimental and control groups].

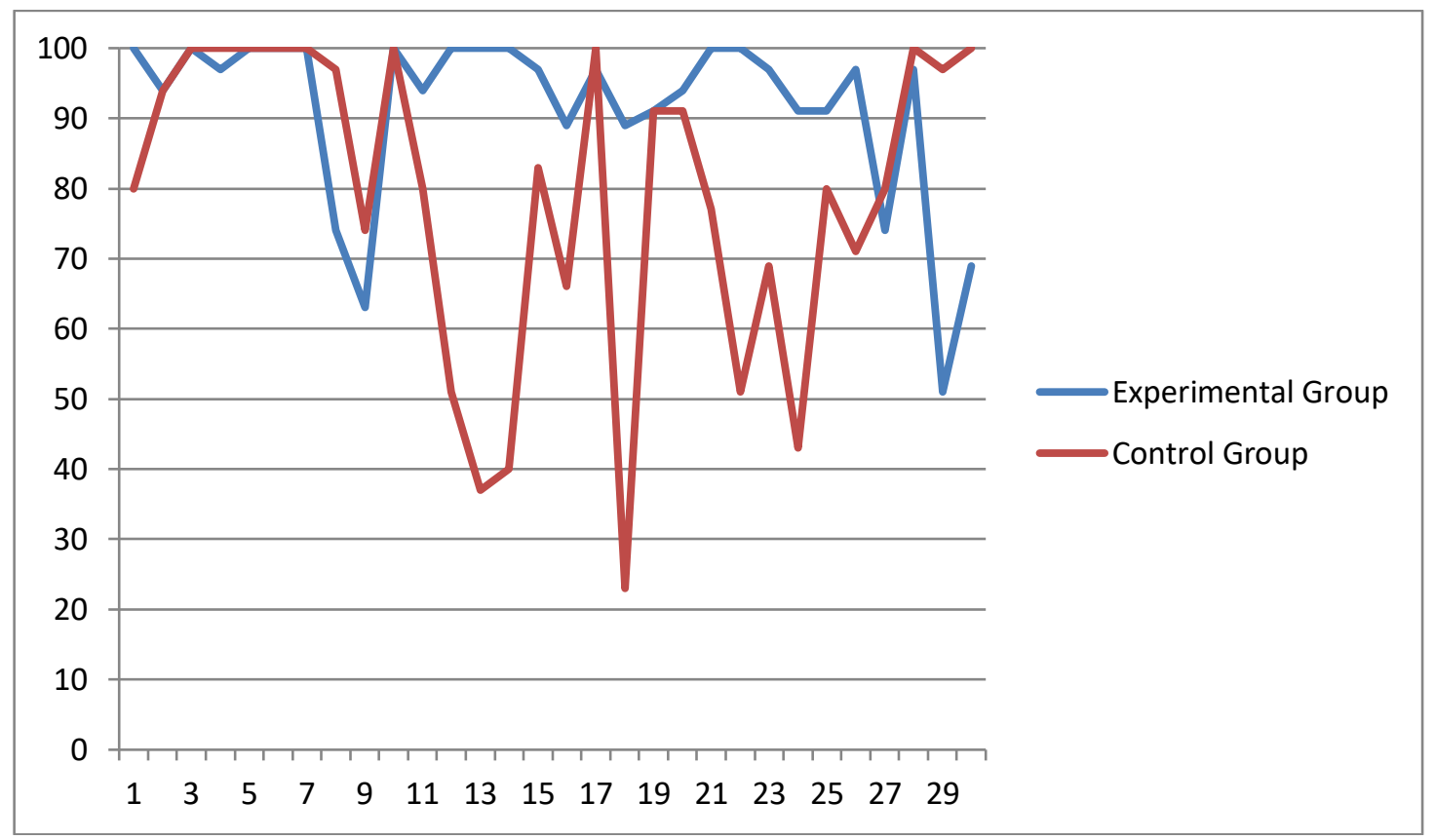

Figure 2 Score of Post-Test for Experimental and Control Groups

Table 3

Comparison between Post-Test of Experimental and Control Groups

\begin{tabular}{cccc}
\hline Groups & Means & Standard Deviation & $\begin{array}{c}\text { Standard Error } \\
\text { Mean }\end{array}$ \\
\hline Experimental & 91.53 & 12.566 & 2.294 \\
Control & 79.17 & 22.588 & 4.124 \\
\hline
\end{tabular}

Table 3 shows the comparison between the post-test of experimental and control groups using SPSS. The mean for experimental group is 91.53 percent, with the standard deviation of 12.566 and standard error mean of 2.294. On the other hand, the mean for control group is 79.17 percent, with the standard deviation of 22.588 and standard error mean of 4.124 . The difference between the mean of post-test for experimental and control groups is 12.36 percent.

The $p$-value for this independent $t$-test is .003. Since $p=.003 \leq .05$, so the null hypothesis is rejected and the alternative hypothesis is accepted. As a conclusion, there is a significant difference between the mean of post-test for the experimental and control groups. The inferential statistics analysed 
INTERNATIONAL JOURNAL OF ACADEMIC RESEARCH IN BUSINESS AND SOCIAL SCIENCES

Vol. 8, No. 10, Oct. 2018, E-ISSN: 222 2-6990 @ 2018 HRMARS

from this study had proven that DoCtor WoRM's Module is effective in improving multiplication skills among Year Four low achievers.

\section{Conclusion}

The results of dependent $t$-test showed that there is a significant difference between the mean of pre-test and post-test for the experimental group. On the other hand, the results of independent $t$ test showed that there is a significant difference between the means of post-test for experimental and control groups. Both inferential statistics had demonstrated the efficacy of DoCtor WoRM's Module for Year Four low achievers. This is in line with the findings of Davrajoo, Tarmizi, Nawawi \& Hassan (2010) that shows that module is an effective teaching aid for mathematics subject. In short, the findings in this study had proven that DoCtor WoRM's Module is effective to improve multiplication skills among Year Four low achievers if compared to the traditional teaching on the same content.

\section{Corresponding Author}

Yoong Soo May

Email: soomayyoong@gmail.com

\section{References}

Ahmad, S.Z. \& Mutalib, A.A. (2016). Conceptual Model of iCAL4LA: Proposing the Components using Comparative Analysis. International Conference on Applied Science and Technology (ICAST 2016).11-13 April 2016, Kedah, Malaysia.

Bird, R. (2012). The Dyscalculia Resource Book: Games and Puzzles for Ages 7-14. London: SAGE Publications Ltd.

Briggs, M. \& Davis, S. (2015). Creative Teaching: Mathematics in the Primary Classroom: Second Edition. New York: Routledge.

Chang, R.C. \& Yang, C.Y. (2016). Developing a Mobile App for Game-Based Learning in Middle School Mathematics Course. Proceedings of the International Conference on Applied System Innovation. Okinawa Convention Center, Japan. 28 May-1 June 2016.

Davrajoo, E., Tarmizi, R.A., Nawawi, M. \& Hassan, A. (2010). Enhancing Algebraic Conceptual Knowledge with Aid of Module using Mastery Learning Approach. Procedia Social and Behavioral Science, 8, 362-369.

Emerson, J. \& Babtie, P. (2014). The Dyscalculia Solution: Teaching Number Sense. London: Bloomsbury Education.

Finesilver, C. \& Rodd, M. (2017). Working Mathematically with Students with Special Educational Needs. Learning to Teach Mathematics in the Secondary School. New York: Routledge Taylor \& Francis Group.

Goos, M., Vale, C., Stillman, G., Makar, K., Herbert, S., \& Geiger, V. (2017). Teaching Secondary School Mathematics Research and Practice for the $21^{\text {st }}$ Century: $2^{\text {nd }}$ Edition. Australia: Allen \& Unwin.

Hsieh, T.C., Lee, M.C., \& Su, C.Y. (2013). Desigining and Implementing a Personalized Remedial Learning System for Enhancing the Programming Learning. 
INTERNATIONAL JOURNAL OF ACADEMIC RESEARCH IN BUSINESS AND SOCIAL SCIENCES

Vol. 8, No. 10, Oct. 2018, E-ISSN: 222 2-6990 @ 2018 HRMARS

Journal of Educational Technology \& Society, 16(4), 32-46.

Ishak, N.M., Yunus, M.M., Rahman, S.A. \& Mahmud, Z. (2010). Effects of FLEP on SelfMotivation and Aspiration to Learn Among Low-Achieving Students: An Experimental Study across Gender. Procedia - Social and Behavioral Sciences, 7, 122-129.

Kang, S.C. (2013, December 5). Malaysia Ranks 52 out of 65 Countries in International Assessment Programme. The Star Online. Retrieved 14 February 2017 from http://www.thestar.com.my/news/nation/2013/12/05/students-score-below-globalaverage-malaysia-ranks-52-out-of-65-countries-in-international-assessment/

Rahman, M.H.A. (2016). Kesan Penggunaan Modul Pengintegrasian Geogebra Topik Trigonometri Terhadap Pencapaian dan Motivasi bagi Murid Berpencapaian Rendah. Master Thesis. Sultan Idris Education University.

Noah, S.M. \& Ahmad, J. (2005). Pembinaan Modul: Bagaimana Membina Modul Latihan dan Modul Akademik. Selangor: Penerbit Universiti Putra Malaysia.

Penny, R.W. (2017). Why Do We Teach Mathematics. Learning to Teach Mathematics in the Secondary School. New York: Routledge Taylor \& Francis Group.

Sangster, M. (2016). Engaging Primary Children in Mathematics. London: Bloomsbury Academic.

Tuckman, B.W. \& Waheed, M.A. (1981). Evaluation an Individualized Science Programme for Community College Students. Journal of Research in Science Teaching, 18, 489-495.

Yoong, S.M. \& Ahmad, N.A. (2018). A Conceptual Framework for DoCtor WoRM's Module in Improving Multiplication Skills among Year Four Low Achievers. International Journal of Academic Research in Business \& Social Sciences, 8(4), 946-957.

Yoong, S.M. \& Ahmad, N.A. (2018). Needs Analysis of DoCtor WoRM's Module in Improving Multiplication Skills among Year Four Low Achievers. International Journal of Academic Research in Business \& Social Sciences, 8(5), 931-944.

Yusof, Y. (2011). The Effectiveness of Visual-Spatial Intelligence Teaching Courseware on Equivalent Fractions for Weak Students. Master Thesis. Universiti Pendidikan Sultan Idris.

Ziegler, G.M. \& Loos, A. (2014). Teaching and Learning "What is Mathematics". Proceedings of the $13^{\text {th }}$ International Congress on Mathematical Education, 66-77. 